Henry K. Gyasi MB CH B FFARCSI, Mohamed Naguib MB B CH M SC

\title{
Atracurium and severe hepatic disease: a case report
}

Airacurium is a new non-depolarising neuromuscular blocking agent, metabolized through Hofmann elimination. A case is presented in which a 45-year-old patient with severe liver disease showed a decreased response to atracurium. The possible causes of resistance to atracurium are discussed. We conclude that atracurium may be used in patients with severe hepatic disease.

\section{Key words}

NEUROMUSCULAR RELAXANTS: atracurium, succinylcholine; ENZYMES: plasma cholinesterase; LIVER: function.

Atracurium besylate is a new non-depolarising neuromuscular blocking agent. It is broken down in the body through Hofmann elimination, a spontaneous non-enzymatic process which is $\mathrm{pH}$ and temperature dependent. ${ }^{1,2}$ The molecule of atracurium may, however, undergo non-specific ester hydrolysis, especially under acidic conditions. In plasma of patients deficient in plasma cholinesterase activity, the degradation of atracurium is unaffected. ${ }^{3}$

We present a case of decreased response to atracurium in a patient with severe liver disease.

\section{Case history}

A 45-year-old male presented for emergency laparatomy for drainage of a liver abscess due to an infected hydatid cyst. He weighed $84 \mathrm{~kg}$, looked very ill, was pyrexial (temperature $38.1^{\circ} \mathrm{C}$ ) and icteric. His blood pressure was $16 / 10.6 \mathrm{KPa}$ (120/ $80 \mathrm{mmHg}$ ), pulse $120 / \mathrm{min}$ and respiratory rate $30 / \mathrm{min}$. He had no peripheral oedema. His central

From the Department of Anaesthesiology, King Faisal University, King Fahd Hospital, P.O. Box 2208, Al-Khobar 31952, Saudi Arabia.

Address correspondence to: Dr. H.K. Gyasi. venous pressure was $0.9 \mathrm{KPa}\left(9 \mathrm{cmH}_{2} \mathrm{O}\right)$. Haemoglobin was $8.9 \mathrm{~g} \cdot \mathrm{dl}^{-1}$ and the test for sickle cell haemoglobin was negative.

This was his first general anaesthetic and there was no family history of anaesthetic problems.

Preoperative serum urea, sodium, potassium and chloride were within normal limits but total bilirubin was $73.5 \mu \mathrm{mol} \cdot \mathrm{L}^{-1}$ (normal $1.71-18.81$ $\mu \mathrm{mol} \cdot \mathrm{L}^{-1}$ ) total protein $85 \mathrm{~g} \cdot \mathrm{L}^{-1}$ (normal $60-80$ $\mathrm{g} \cdot \mathrm{L}^{-1}$ ) and albumin $27 \mathrm{~g} \cdot \mathrm{L}^{-1}$ (normal $35-48 \mathrm{~g} \cdot \mathrm{L}^{-1}$ ). The preoperative chest $x$-ray and ECG were normal.

$\mathrm{He}$ was started on a course of metronidazole $250 \mathrm{mg}$, gentamycin $80 \mathrm{mg}$ and Vitamin $\mathrm{K} 10 \mathrm{mg}$ intravenously. No premedication was given.

The patient arrived in the operating room with a solution of Ringer's Lactate in five per cent dextrose running via a peripheral vein. A baseline blood pressure was measured and subsequently, every five minutes by an electronic oscillotonometer (Dinamap). The ECG was monitored continuously by a Medishield M1 monitor.

The thumb of a restrained arm was attached to a force-displacement transducer to record the response of the adductor pollicis to peripheral nerve stimulation of the ulnar nerve at the elbow via surface electrodes using a myotest nerve stimulator (Biometer) and a continuous pen and paper recorder (Myograph, Biometer). Train of four (TOF) stimulation of $0.2 \mathrm{msec}$ duration and 2 hertz frequency every $12 \mathrm{sec}$ was used. Temperature was measured by means of a nasopharyngeal thermistor probe.

After pre-oxygenation for three minutes, anaesthesia was induced with thiopentone $300 \mathrm{mg}$, succinylcholine $80 \mathrm{mg}$ and the trachea was intubated with a cuffed oral tube after complete suppression of twitch response. Anaesthesia was maintained with nitrous oxide 70 per cent in oxygen and phenoperidine $3 \mathrm{mg}$ intravenously. Ventilation was controlled to maintain an end-tidal carbon dioxide tension of $4.0 \mathrm{KPa}(30 \mathrm{mmHg})$ as measured by a Datex Normocap infra-red carbon dioxide analyser. 
TABLE Dose, onset, duration and intensity of block with atracurium

\begin{tabular}{|c|c|c|c|c|c|c|c|}
\hline Dose of atracurium (mg) & 42 & 8.4 & 8.4 & 8.4 & 8.4 & 8.4 & $8.4^{*}$ \\
\hline Onset of action (s) & 30 & 33 & 30 & 57 & 32 & 32 & 45 \\
\hline Duration of action (min) & 13.65 & 4.65 & 2.35 & 8.4 & 5.5 & 3.85 & 4.08 \\
\hline $\begin{array}{l}\text { Twitch height at time of } \\
\text { injection (\% of control) }\end{array}$ & 40 & 12 & 12 & 16 & 12 & 16 & 16 \\
\hline $\begin{array}{l}\text { Mirimum Iwitch height } \\
\text { following injection }\end{array}$ & 0 & 8 & 10 & 4 & 8 & 8 & 4 \\
\hline Duration of incremental do & $8 \pm 1.8$ & $\operatorname{ean} \pm$ & & & & & \\
\hline
\end{tabular}

An initial bolus of atracurium $0.5 \mathrm{mg} \cdot \mathrm{kg}^{-1}$ was given followed by increments of $0.1 \mathrm{mg} \cdot \mathrm{kg}^{-1}$ as required (see text).

*The last dose of atracurium was given $4.08 \mathrm{~min}$ before reversal with nenstigmine and atropine.

There was no response to peripheral nerve stimulation for 19 minutes following succinylcholine injection and after 21 minutes twitch response had recovered to only 20 per cent of control twitch height. There was no fade to TOF stimulation. Neuromuscular blockade was subsequently maintained with atracurium $0.5 \mathrm{mg} \cdot \mathrm{kg}^{-1}$ body weight and incremental doses of $0.1 \mathrm{mg} \cdot \mathrm{kg}^{-1}$ whenever the first twitch of TOF stimulation exceeded ten per cent of control twitch height on at least three successive stimulations.

Thirty seconds after the initial dose of atracurium, there was complete suppression of the twitch response. Recovery of the first twitch of TOF stimulation to ten per cent of control twitch height took 13.65 minutes. Subsequently, six incremental doses of atracurium were given (Table) and the mean duration of effect of each dose was 4.8 minutes. At no time following the first incremental dose did complete twitch inhibition recur.

During surgery, a large liver abscess was drained, later found to be an infected echinococcus cyst. Two units of blood were transfused in addition to two litres of Ringer's Lactate solution. Blood pressure, pulse and CVP readings were unchanged throughout surgery. Arterial blood gases were: $\mathrm{pH}$ 7.39, $\mathrm{PaCO}_{2} 3.85 \mathrm{~K} \mathrm{~Pa}, \mathrm{PaO}_{2} 12.1 \mathrm{kPa}$, oxygen saturation 97 per cent, bicarbonate $16 \mathrm{mmol} \cdot \mathrm{l}^{-1}$ and base excess $-6.6 \mathrm{mmol} \cdot \mathrm{l}^{-1}$.

Anaesthesia lasted for 70 minutes and residual neuromuscular block was reversed by neostigmine $3 \mathrm{mg}$ and atropine $1.5 \mathrm{mg}$. At the time of reversal, only the first response to TOF stimulation was present and this was 20 per cent of control twitch height. The response to neostigmine was rapid and the TOF ratio, the ratio of the fourth response to the first of TOF stimulation, had recovered to 0.75 , six minutes after reversal. The patient regained consciousness ten minutes after completion of surgery. He was extubated and sent to the recovery room where his progress was uneventful

Samples of venous blood were taken for plasma cholinesterase estimation during surgery and on the third and fifth postoperative days. The enzyme activity was measured with the plasma cholinesterase pack (PChE pack, Dupont) and the Dupont Automatic Clinical Analyser. * Plasma cholinesterase activities were $4.4,4.6$ and 4.2 units $L^{-1}$ respectively (normal values $7-19$ units $\cdot \mathrm{L}^{-1}$ ). No qualitative studies of plasma cholinesterase were done because the necessary reagents were not available.

The subsequent postoperative course was uneventful and the patient was discharged 14 days postoperatively.

\section{Discussion}

Foldes et al. found that the duration of action of $0.5 \mathrm{mg} \cdot \mathrm{kg}^{-1}$ atracurium in normal patients was 43.6 minutes and for $0.1 \mathrm{mg} \cdot \mathrm{kg}^{-1}$ increments, 20.9 minutes. ${ }^{4}$ This is in agreement with our own observations with atracurium in patients with normal liver function. In contrast, the duration of action of atracurium in this patient was considerably shorter: 13.65 minutes for the initial dose and 4.8 minutes for each incremental dose.

There are no previous reports of the use of atracurium in patients with severe hepatic disease but the use of other non-depolarising muscle relaxants in such patients is well documented. ${ }^{5-11}$

* Plasma cholinesterase activity is measured by the change in absorbance at $600 \mathrm{~nm}$ following the reduction of butyrylthiocholine to thiocholine. 
Dundee and Gray reported resistance to d-tubocurarine in the presence of liver disease ${ }^{5}$ and this has been attributed to increased binding to globulins, ${ }^{6,7}$

There is increased sensitivity to alcuronium in patients with hypoalbuminaemia. ${ }^{8}$ In clinical studies with pancuronium, Stovner found no relationship between this relaxant and serum protein fractions. ${ }^{9}$ In obstructive liver disease, total body clearance of pancuronium is decreased, ${ }^{10}$ resulting in a slower rate of recovery from the drug. In patients with cirrhotic liver disease, there is an increased distribution volume for pancuronium, resulting in a slow onset of paralysis, an increased dose to maintain the same degree of paralysis and a delayed rate of recovery because of the prolonged elimination half life. ${ }^{\prime \prime}$

Foldes and Deery found that 82 per cent of atracurium was bound to plasma proteins, compared to 77 per cent of d-tubocurarine. ${ }^{12}$

In chronic liver disease, hypoalbuminaemia is accompanied by hyperglobulinaemia. ${ }^{13}$ Increased binding of atracurium to globulin could therefore explain the resistance to atracurium observed in this patient. Hyperbilirubinaemia, hypoalbuminaemia and low plasma cholinesterase activity, all of which were present in this patient, collectively indicate severe hepatic dysfunction. Increased globulin will mean that more binding sites for atracurium will be available and it is when these sites are saturated that excess drug will be available for action at other sites, including the neuromuscular junction.

An increased distribution volume cannot explain the decreased response to atracurium since unlike the effect with pancuronium, both onset and recovery were normal.

Prior administration of succinylcholine increases the intensity but not the duration of atracurium blockade ${ }^{14}$ However, in our patient, the intensity of atracurium blockade was not affected by the prior administration of succinylcholine and the duration was shorter.

Electrolytes and $\mathrm{pH}$ were normal and would therefore not alter the metabolism of atracurium in this patient.

The slow recovery following the administration of succinylcholine in our patient may be due to plasma cholinesterase deficiency from chronic liver disease. The enzyme is synthesised in the liver and the enzyme levels tend to fall in chronic liver disease. ${ }^{15}$ Furthermore, plasma cholinesterase levels tend to parallel serum albumin levels in chronic liver disease. ${ }^{16}$ The nephrotic syndrome is the only condition in which hypoalbuminaemia and a high plasma cholinesterase activity regularly co-exist. ${ }^{17}$

Other causes of plasma cholinesterase deficiency have been described and these may be physiological, inherited, acquired or iatrogenic. For a full review of these causes, the reader is referred to an excellent article by Whittaker. ${ }^{18}$

This case shows that atracurium can be safely used in patients with severe hepatic disease. Dose requirements may be greater than in normal patients and monitoring of neuromuscular function is recommended in order to determine each patient's requirements for atracurium. It also confirms the observation that in patients with plasma cholinesterase deficiency, the metabolism of atracurium is not prolonged. ${ }^{1,3}$

\section{Acknowledgements}

The authors wish to thank Prof. R. Bodman and Dr. Y. Adu Gyamfi for their advice and Mr. Emmanuel Lapak for typing the manuscript.

\section{References}

I Stenlake JB, Waigh RD, Urwin J, Dewar GH, Cooker $C G$. Atracurium: conception and inception. Br J Anaesth 1983; 55 (Suppl. 1): 3S-10S.

2 Chapple DJ, Clark JS. Pharmacological action of breakdown products of atracurium and related substances. Br J Anaesth. 1983; 55 (Suppl. 1): 11S$15 S$.

3 Merrett RA, Thompson CW, Webb FW. In vitro degradation of atracurium in human plasma. $\mathrm{Br} \mathbf{J}$ Anaesth 1983; 55: 61-6.

4 Foldes FF, Nagashima H, Boros M, Tasfonyi E, Fitzal S, Agoston S. Muscular relaxation with atracurium, vercuronium and duador under balanced anaesthesia. Br J Anaesth 1983; 55 (Suppl. 1): $97 \mathrm{~S}-103 \mathrm{~S}$

5 Dundee JW, Gray TC. Resistance to d-tubocurarine chloride in the presence of liver damage. Lancet $1953 ; 2,16-7$.

6 Aladjemoff $L$, Dilestein S, Shafir $E$. Binding of d-tubocurarine chloride to plasma proteins. J. Pharmacol Exp Ther 1958; 123: 43-8.

7 Baraka A, Gabali F. Correlation between tubocurarine requirements and plasma protein pattern. $\mathrm{Br}$ J Anaesth 1968; 40: 89-93. 
8 Stovner J, Theodorsen L, Bjelke E. Sensitivity to tubocurarine and alcuronium with special reference to plasma protein pattern. Br J Anaesth 1971; 43: 385.

9 Stowner J, Theodorsen L, Bjelke E. Sensitivity to gallamine and pancuronium with special reference to serum proteins. Br J Anaesth 1971; 43: 953.

10 Somogyi AA, Shanks CA, Triggs EJ. Disposition kinetics of pancuronium bromide in patients with total biliary obstruction. Br J Anaesth 1977; 49: 1103-8.

11 Duvaldestin P, Agoston S, Henzel D et al. Pancuronium pharmacokinetics in patients with liver cirrhosis. Br J Anaesth 1978; 50: 131-6.

12 Foldes $F$, Deery $A$. Protein binding of atracurium and other short acting neuromuscular blocking agents and their interaction with human cholinesterase. $\mathrm{Br}$ J Anaesth 1983; 55 (Suppl. 1): 31S-34S.

13 Macleod J. Principles and Practice of Medicine. 2nd Ed. Edinburgh, Churchill Livingstone: 1978; 430.

14 Stirt JA, Karz RL, Murray AL, Schelhl DL, Lee C. Modification of atracurium blockade by halothane and suxamethonium. A review of clinical experience. Br J Anaesth 1983; 55 (Suppl. 1): 71S-5S.

15 Kaufman $K$. Serum cholinesterase activity in the normal individual and in people with liver disease. Ann Int Med 1954; 41: 533-45.

16 Faber $M$. The relationship between serum cholinesterase and serum albumin. Acta Med Scand 1943; 114: 72-91.

17 Kunkel HG, Ward SM. Plasma esterase activity in patients with liver disease and nephrotic syndrome. Journal of Experimental Medicine 1947; 86: 325-37.

18 Whittaker $M$. Plasma cholinesterase variants and the anaesthetist. Anaesthesia 1980; 35: 174-97.

\section{Résumé}

L'atracurium est un nouveau bloqueur neuro-musculaire non-dépolarisant métabolisê par élimination de Hofmann. Un cas est présenté dans lequel un patient de 45 ans avec une atteinte hépatique sêvère a présenté une diminution de la réponse à l'atracurium. Les causes possibles de la résistance d l'atracurium sont discutées. On conclut que l'atracurium peut être utilisé chez les patients avec une atteinte hépatique sévère. 